\title{
DIFFERENTIAL EXPRESSION OF TFF GENES AND PROTEINS IN BREAST TUMORS
}

Maja Tolušić Levak ${ }^{1}$, Martina Mihalj ${ }^{2}$, Ivan Koprivčićc ${ }^{3,7}$, Ivana Lovrićc ${ }^{1,4}$, Sanja Novak2, Nikola Bijelić ${ }^{1}$, Mirela Baus-Lončar ${ }^{5}$, Tatjana Belovari ${ }^{1}$, Kristina Kralik ${ }^{6}$ and Biljana Pauzar ${ }^{1,8}$

${ }^{1}$ Department of Histology and Embryology, Faculty of Medicine, Josip Juraj Strossmayer University of Osijek, Osijek, Croatia; ${ }^{2}$ Department of Physiology and Immunology, Faculty of Medicine, Josip Juraj Strossmayer University of Osijek, Osijek, Croatia; ${ }^{3}$ Department of Anatomy and Neuroscience, Faculty of Medicine, Josip Juraj Strossmayer University of Osijek, Osijek, Croatia; ${ }^{4}$ Department of Anatomy, Histology and Embryology, Faculty of Dental Medicine and Health, Josip Juraj Strossmayer University of Osijek, Osijek, Croatia; ${ }^{5}$ Department of Molecular Medicine, Ruđer Bošković Institute, Zagreb, Croatia; ${ }^{6}$ Department of Medical Statistics and Informatics, Faculty of Medicine, Josip Juraj Strossmayer University of Osijek, Osijek, Croatia; ${ }^{7}$ Department of Surgery, Osijek University Hospital Centre, Osijek, Croatia; ${ }^{8}$ Department of Clinical Cytology, Osijek University Hospital Centre, Osijek, Croatia

SUMMARY - The objective of this study was to determine differential expression of TFF1, TFF2 and TFF3 genes and proteins in breast tumor subtypes. In addition, we investigated the correlation between $T F F$ genes within tumor subgroups, and $T F F$ genes with clinical and pathologic characteristics of the tumor. Study group included 122 patients with surgically removed breast tumors. Samples were investigated using qRT-PCR and immunohistochemistry. TFF1 and TFF3 genes and proteins were expressed in breast tumors, while the levels of TFF2 gene and protein expression were very low or undetectable. TFF1 was significantly more expressed in benign tumors, while TFF3 was more expressed in malignant tumors. Gene and protein expression of both TFF1 and TFF3 was greater in lymph node-negative tumors, hormone positive tumors, tumors with moderate levels of Ki67 expression, and in grade II tumors. A strong positive correlation was found between TFF1 and TFF3 genes, and the expression of both negatively correlated with Ki67 and the level of tumor histologic differentiation. Our results suggest that TFF1 and TFF3, but not TFF2, may have a role in breast tumor pathogenesis and could be used in the assessment of tumor differentiation and malignancy.

Key words: Neoplasm Proteins; Breast Neoplasms; Immunohistochemistry; Polymerase Chain Reaction; Lymph Nodes; Ki-67 Antigen; Biomarkers

\section{Introduction}

Breast cancer is the most common form of cancer affecting women worldwide, and is a global health, economic and social problem ${ }^{1}$. Malignant breast tumors are a highly heterogeneous tumor group and are therefore difficult to classify into uniform subgroups

Correspondence to: Biljana Pauzar, $M D, P h D$, Osijek University Hospital Centre, Josipa Huttlera 4, 31000 Osijek, Croatia

E-mail: bpauzar@gmail.com

ORCID: 0000-0003-0978-0827

Received February 28, 2018, accepted March 20, 2018 that could be used to assess malignancy of the tumor, choose appropriate treatment, and thus ensure longterm survival of patients ${ }^{2}$. According to St. Gallen consensus, which is based on estrogen receptor (ER), progesterone receptor (PR) and human epidermal growth factor receptor (HER2) expression, tumors are divided into four subgroups: Luminal A (Lum A), Luminal B (Lum B), HER2 positive (HER2 pos) and triple negative (triple neg) ${ }^{3}$. This consensus can apply to all types of breast tumors regardless of their histologic type and is of substantial clinical significance because it helps assess tumor malignancy and select ap- 
propriate treatment ${ }^{4}$. However, breast tumors still exhibit substantial histologic and clinical heterogeneousness. Therefore, new biomarkers are needed to improve diagnosis, assess progression of the disease and choose appropriate tumor therapy to ease treatment and prolong patient survival ${ }^{5}$.

Trefoil factor family (TFF) proteins are small secretory proteins expressed mainly in the gastrointestinal tract, but are also found in many other human tissues. The trefoil factor family consists of three members (TFF1, TFF2 and TFF3) expressed in different human tissues ${ }^{6,7}$. TFF proteins participate in numerous physiologic and pathologic processes through different mechanisms. Their versatile functions are important in mucosal restitution and repair processes, cell adhesion, motility, apoptosis, and angiogenesis ${ }^{8-10}$. They are also found in different tissues during embryonic development ${ }^{11}$. Apart from healthy tissues, TFF proteins are expressed in various pathologically changed tissues, such as inflamed gut in the inflammatory bowel disease and malignant tumors, including breast cancer ${ }^{12}$. There is a controversy regarding the impact of TFF1 protein on the malignant properties of breast cancer. Some studies indicate that it enhances breast cancer development ${ }^{13-16}$, whereas others propose a tumor-suppressive role ${ }^{17-20}$. At first, $T F F 2$ protein was not found in the epithelium of either normal or pathologically changed breasts ${ }^{21}$. Later experiments have revealed that TFF2 protein is expressed in breast cancer cell line, both in normal breast cells and in breast tumor cells, and has a motogenic effect on breast cancer cells in cell culture; however, it is secreted in very small amounts compared to TFF1 and TFF3 proteins $^{22}$. According to experiments on breast cancer cell lines, TFF2 protein is considered a negative prognostic biomarker ${ }^{23-25}$. Past studies of TFF3 protein have indicated that it promotes invasiveness, prevents apoptosis of tumor cells, and stimulates neoangiogenesis in tumor tissue, allowing tumor progression and promoting its malignancy. TFF3 protein has been therefore categorized as a biomarker indicating poor prognosis, even though it is expressed more strongly in hormone receptor-positive tumors, which have better prognosis $^{9,26-29}$.

The objective of this study was to determine differential expression of $T F F$ genes and TFF proteins in various breast tumor subtypes. Additionally, we assessed correlation between TFF genes within the tu- mor subgroups and their correlation with the clinical and pathologic characteristics of the tumor in order to determine their value as potential biomarkers.

Our results suggested that TFF1 and TFF3, unlike TFF2, may have a role in breast tumor pathogenesis and could be used in the assessment of tumor malignancy only in particular breast tumor subgroups. Increased expression of TFF1 could be used as a potential biomarker indicating good prognosis, whereas TFF3 could be helpful in tumor status assessment.

\section{Patients and Methods}

\section{Study population}

The study included 122 female patients that underwent surgery at the Department of Surgery, Osijek University Hospital Centre for obvious breast tumor. The study lasted for 30 months (2014-2016). The test group comprised of 91 surgical patients with malignant breast tumors and 31 patients with fibroadenomas (benign breast tumors) surgically removed ${ }^{30}$. On analyzing the data obtained, we subdivided the malignant group depending on hormone receptor status (2011 St. Gallen consensus) ${ }^{4}$, histologic grade (Nottingham Grading System) $)^{31}$, affection of lymph nodes by metastases, and levels of expression of the Ki67 proliferation marker.

\section{Gene analysis}

Tumor samples for gene expression analysis were obtained during surgical procedures and were immediately stored in the $\mathrm{RNAlater}^{\circledR}$ total RNA integrity preservation solution (Applied Biosystems, USA). The collected samples were kept at room temperature for one hour and afterwards stored at $-80{ }^{\circ} \mathrm{C}$ until total RNA isolation process.

Tissue samples were homogenized with liquid nitrogen. Total RNA isolation was performed using the TRI Reagent (Life Technologies, USA) according to the manufacturer's protocol. Total RNA was diluted with $30 \mu \mathrm{L}$ of DEPC-treated water (Santa Cruz, USA) and stored at $-80^{\circ} \mathrm{C}$. Amplification Grade DNase I (Sigma-Aldrich, USA) commercial kit was used to remove DNA molecules from RNA samples, following the manufacturer's protocol. NanoPhotometer ${ }^{\circledR}$ P-Class P330-30 micro volume spectrophotometer (Implen, Germany) was used to determine RNA 
Table 1. Primer sequences and primer annealing temperature used on $q R T-P C R$ analysis

\begin{tabular}{|l|l|l|}
\hline Gene & Sequence & Annealing temperature $\left({ }^{\circ} \mathrm{C}\right)$ \\
\hline TFF1 & $\begin{array}{l}\text { FOR: TTTGGAGCAGAGAGGAGGCAATG } \\
\text { REV: ACCACAATTCTGTCTTTCACGGGG }\end{array}$ & $63.3^{\circ} \mathrm{C}$ \\
\hline TFF2 & $\begin{array}{l}\text { FOR: CCCATAACAGGACGAACTGC } \\
\text { REV: GCACTGATCCGACTCTTGCT }\end{array}$ & $55.7^{\circ} \mathrm{C}$ \\
\hline TFF3 & $\begin{array}{l}\text { FOR: CTTGCTGTCCTCCAGCTCT } \\
\text { REV: CCGGTTGTTGCACTCCTT }\end{array}$ & $64.5^{\circ} \mathrm{C}$ \\
\hline ACTB & $\begin{array}{l}\text { FOR: AAGCACCAGGGCGTGAT } \\
\text { REV: TCGTCCCAGTTGGTGACGA }\end{array}$ & $63.3^{\circ} \mathrm{C}$ \\
\hline
\end{tabular}

TFF1 = trefoil factor family 1 gene; TFF2 = trefoil factor family 2 gene; TFF3 = trefoil factor family 3 gene; $\mathrm{ACTB}=$ actin beta gene

concentration and sample purity. Isolated RNA was transcribed into cDNA using reverse transcriptase from the PrimeScriptTM RT reagent Kit (Perfect Real Time, Takara, USA) commercial kit. The reaction was performed in a CFX96 device (Bio Rad, USA) for 120 minutes at $37^{\circ} \mathrm{C}$, followed by 5 seconds at $85^{\circ} \mathrm{C}$. The reaction mixture was then cooled to $4{ }^{\circ} \mathrm{C}$.

Nucleotide sequences for the primers were chosen using the primer designing program available on the website http://eu.idtdna.com/site and literature ${ }^{32}$. Optimal reaction conditions in which an efficiency ranging from $95 \%$ to $100 \%$ was achieved were determined for each individual gene primer pair. Each sample was processed in duplicate. qRT-PCR reactions were performed in the following conditions: enzyme activation at $95^{\circ} \mathrm{C}$ for 30 seconds followed by 40 cycles of denaturation at $95{ }^{\circ} \mathrm{C}$ for 5 seconds, primer annealing at $55-60{ }^{\circ} \mathrm{C}$ for 5 seconds (40 cycles) and 10 seconds at $55-63{ }^{\circ} \mathrm{C}$, with the final disassociation step. qRT-PCR was performed on a Real Time PCR System Bio Rad CFX96 device. Actin beta (ACTB) gene expression was used to normalize gene expression ${ }^{33}$. Primer sequences and annealing temperature used for qRTPCR analysis are presented in Table 1.

\section{Protein analysis}

Protein expression was accompanied by immunohistochemical sample analysis. The patient cohort comprised of 75 surgical patients with breast tumors removed, 15 (20\%) of which were fibroadenoma samples (benign tumors) and 60 (80\%) malignant tumor samples. All samples were collected at the Department of Pathology and Forensic Medicine, Osijek University Hospital Centre. All samples were subjected to an initial histopathologic analysis and were histopathologically reconfirmed by an independent pathologist. Formalin-fixed and paraffin-embedded sections of breast tumor tissue were deparaffinized and rehydrated. Endogenous peroxidase blocking using $0.3 \%$ hydrogen peroxide (15 minutes) was performed on the sections, followed by antigen retrieval in citrate buffer $(\mathrm{pH}=6.0)$ by heating in a microwave oven for $5 \mathrm{~min}$ utes. The primary antibody was applied to the slides, and incubated at $4{ }^{\circ} \mathrm{C}$ overnight. Primary antibodies used in this study were anti-TFF1 (Anti-Estrogen Inducible Protein pS2 antibody ab92377, Abcam, USA), anti-TFF2 (Anti-Spasmolytic Polypeptide antibody ab131147, Abcam, USA) and anti-TFF3 (purified polyclonal rabbit anti-TFF3 antibody, proprietary, self-made $)^{34}$. Negative controls were incubated with phosphate-buffered saline (PBS, $\mathrm{pH}=7.4$ ) instead of primary antibody. Human stomach tissue was used as positive control for TFF1 and TFF2 proteins, and human colon tissue was used as positive control for TFF3 protein. Following primary antibody incubation, the sections were washed in PBS with Tween (0.05\%) (Sigma Aldrich, USA) four times. This was followed by application of secondary antibody (affinity purified, biotinylated goat anti-rabbit IgG, Vector Laboratories, USA), left at room temperature for 120 minutes. This procedure was followed by four more washes in PBS with $0.05 \%$ Tween, after which the slides were incubated with streptavidin conjugated to horseradish peroxidase (Streptavidin-HRP, Vector Laboratories, USA) at room temperature for 45 minutes. After four more washes in PBS with Tween, 3.3'-diaminobenzidine solution was applied (DAB Peroxidase (HRP) Substrate Kit, Vector Laboratories, USA). After four 
washes in PBS with Tween, the slides were counterstained with hematoxylin and dehydrated in appropriate solutions. Slides were mounted using Canada balsam and covered with coverslips. The analysis was performed at the Histology Laboratory, Faculty of Medicine in Osijek.

The slides thus obtained were analyzed by two independent histologists. They were photographed using an Olympus ${ }^{\circledR} \mathrm{C}-5050$ digital camera connected to an Olympus ${ }^{\circledR}$ BX-50 microscope and QuickPHOTO Pro software. The histomorphological analysis determined the existence, proportion and signal strength of TFF protein expression in individual samples using the Modified Quick Score (Q) method of immunohistochemical staining ${ }^{35,36}$. Modified Quick Score method is presented in Table 2 .

Table 2. Modified Quick Score (Q) method for immunohistochemistry protein expression analysis

\begin{tabular}{|l|l|}
\hline Proportion score (A) & Intensity score (B) \\
\hline $\begin{array}{l}\text { No signal }<1 \%-0 \\
\text { Proportion of positive } \\
\text { cells } 1 \%-10 \%-1 \\
\text { Proportion of positive } \\
\text { cells } 11 \%-33 \%-2\end{array}$ & Weak signal - 1 \\
$\begin{array}{l}\text { Proportion of positive } \\
\text { cells 34\%-66\% - } 3 \\
\text { Proportion of positive } \\
\text { cells } 67 \%-100 \%-4\end{array}$ & Strong signal - 3 \\
\hline
\end{tabular}

$\mathrm{Q}=\mathrm{A}+\mathrm{B}$, where $\mathrm{Q}$ marks the Quick Score total result; $\mathrm{A}=$ proportion score; $\mathrm{B}=$ intensity score; minimum $\mathrm{Q}$ score was 0 and maximum was 7 .

\section{Statistical methods}

Sample size was defined based on preliminary research results. A minimum sample size of 22 subjects per group or 44 subjects in 2 groups was required to detect a 0.4 effect with $\alpha=0.05$ and test strength of 0.8 . Category data was presented in absolute and relative frequencies. Numerical data were described by median and interquartile range limits. The $\chi^{2}$-test and, where necessary, Fisher exact test were used to test category variable differences. The Shapiro-Wilk test was used to test the normality of numeric variable distribution. The Mann-Whitney U test was used to test numeric variable differences due to deviations from normal distribution. Spearman's rank correlation coefficient was used for correlation assessment. All p-values were twosided. Materiality level was set to $\alpha=0.05$. MedCalc statistical software (version 16.2.0, MedCalc Software bvba, Ostend, Belgium) was used on statistical analysis. GraphPad Prism software (version 6, GraphPad Software, Inc., USA) was used to make the figures.

\section{Compliance with ethical standards}

An informed consent was obtained from all patients included in the study. The study obtained approval from local ethics committees, the Ethics Committee of the Osijek University Hospital Centre (251:15401-3/2013) and Ethics Committee of the Faculty of Medicine, Josip Juraj Strossmayer University in Osijek (2158-61-07-15-125), and was performed in accordance with the ethical standards laid down in the 1964 Declaration of Helsinki.

\section{Results}

\section{Patient population and clinicopathologic characteristics}

The study included 122 patients, age median 62 years (interquartile range 45-74 years), ranging from 18 to 88 years of age. Thirty-one (25\%) patients had benign tumor (fibroadenomas) and 91 (75\%) had malignant tumor. The subjects with malignant tumors were considerably older, age median 68 years (interquartile range $57-76$ years; $\mathrm{p}<0.001$ ). Body mass index (BMI) was considerably higher in the group of subjects with malignant tumors as compared to subjects with benign tumors (fibroadenoma). Within the malignant group, 78 (85.7\%) tumors were hormone receptor-positive and 13 (14.3\%) tumors were hormone receptor-negative. According to the St. Gallen consensus, there were 20 (22\%) Lum A, 58 (63.7\%) Lum B, 4 (4.4\%) Her 2 positive and 9 (9.9\%) triple negative tumors (Table 3). Within the malignant group, 50 (54.9\%) subjects had metastases in lymph nodes, whereas $41(45.1 \%)$ subjects did not have metastases in lymph nodes. Histologic differentiation grade, Ki67 level of expression and other pathologic characteristics of the samples are presented in Table 3.

\section{TFF gene expression}

The expression of TFF1 mRNA was substantially higher in the benign tumor group consisting of subjects with fibroadenomas compared to subjects from 
Table 3. Patient and clinicopathologic characteristics

\begin{tabular}{|c|c|c|c|c|}
\hline \multicolumn{5}{|c|}{ Patient characteristics } \\
\hline & Benign group & Malignant group & Total & $\mathrm{p}$ value \\
\hline $\mathrm{n}$ & 31 & 91 & 122 & \\
\hline Age (yrs) & $\begin{array}{l}32 \\
(26-43)\end{array}$ & $\begin{array}{l}68 \\
(57-76)\end{array}$ & $\begin{array}{l}62 \\
(45-74)\end{array}$ & $<0.001^{*}$ \\
\hline BMI & $\begin{array}{l}21.8 \\
(20.4-26.2)\end{array}$ & $\begin{array}{l}26.9 \\
(24.2-30.5)\end{array}$ & $\begin{array}{l}25.9 \\
(22-29.08)\end{array}$ & $0.002^{*}$ \\
\hline Menopause & $5 / 31(16.1 \%)$ & $80 / 91(87.9 \%)$ & $85 / 122(69.7 \%)$ & $<0.0011^{* *}$ \\
\hline \multicolumn{5}{|c|}{ Pathologic characteristics } \\
\hline \multicolumn{5}{|c|}{ Tumor type (St. Gallen consensus) } \\
\hline \multirow{4}{*}{\multicolumn{2}{|c|}{ Malignant tumors }} & Luminal A & \multirow{4}{*}{\multicolumn{2}{|c|}{\begin{tabular}{|l|}
$20 / 91(22 \%)$ \\
$58 / 91(63.7 \%)$ \\
$4 / 91(4.40 \%)$ \\
$9 / 91(9.90 \%)$ \\
\end{tabular}}} \\
\hline & & Luminal B & & \\
\hline & & Her 2 positive & & \\
\hline & & Triple negative & & \\
\hline \multicolumn{5}{|l|}{ Metastasis } \\
\hline \multirow{2}{*}{\multicolumn{2}{|c|}{ Malignant tumors }} & Lymph node negative & \multirow{2}{*}{\multicolumn{2}{|c|}{\begin{tabular}{|l|}
$50 / 91(54.9 \%)$ \\
$41 / 91(45.1 \%)$
\end{tabular}}} \\
\hline & & Lymph node positive & & \\
\hline \multicolumn{5}{|c|}{ Tumor differentiation } \\
\hline \multirow{3}{*}{\multicolumn{2}{|c|}{ Malignant tumors }} & $\begin{array}{l}\text { Well-differentiated } \\
\text { tumors } \\
\text { (grade I) }\end{array}$ & \multicolumn{2}{|l|}{$22(24.2 \%)$} \\
\hline & & $\begin{array}{l}\text { Moderately } \\
\text { differentiated tumors } \\
\text { (grade II) }\end{array}$ & \multicolumn{2}{|l|}{$42(46.2 \%)$} \\
\hline & & $\begin{array}{l}\text { Poorly differentiated } \\
\text { tumors } \\
\text { (grade III) }\end{array}$ & \multicolumn{2}{|l|}{$27(29.7 \%)$} \\
\hline \multicolumn{5}{|c|}{ Ki67 (\%) } \\
\hline \multirow{3}{*}{\multicolumn{2}{|c|}{ Malignant tumors }} & $\begin{array}{l}\text { Low } \\
(0-15 \%)\end{array}$ & \multicolumn{2}{|l|}{$10(11 \%)$} \\
\hline & & $\begin{array}{l}\text { Moderate } \\
(16 \%-30 \%)\end{array}$ & \multicolumn{2}{|l|}{$28(30.8 \%)$} \\
\hline & & $\begin{array}{l}\text { High } \\
(31 \%-100 \%)\end{array}$ & \multicolumn{2}{|l|}{$53(58.2 \%)$} \\
\hline
\end{tabular}

$\mathrm{n}=$ number of patients; $\mathrm{BMI}=$ body mass index; "Mann Whitney $\mathrm{U}$ test, data are presented as median and interquartile range limits, $\mathrm{p}<0.05$ was considered significant; **Fisher exact test, $\mathrm{p}<0.05$ was considered significant

the malignant group ( $\mathrm{p}=0.048$ ) (Fig. 1, panel A). Our study revealed a very low level of TFF2 mRNA expression in benign breast tumors and extremely low TFF2 expression in malignant breast tumors, thus TFF2 was not expressed (Fig. 7, panel A). TFF3 mRNA expression was higher in the malignant tumor group, but statistically significant difference was not noted ( $\mathrm{p}=0.44)$ (Fig. 1, panel A). Within the malig- nant group, both TFF1 and TFF3 were expressed more strongly in the hormone receptor-positive tumor group (Fig. 1, panel B), but only TFF3 exhibited a statistically significant mRNA expression difference $(p=0.004)$ (Fig. 1, panel B). Comparing the results between the groups defined according to St. Gallen consensus, we found that TFF1 was expressed most strongly in Lum A subgroup and TFF3 was most 


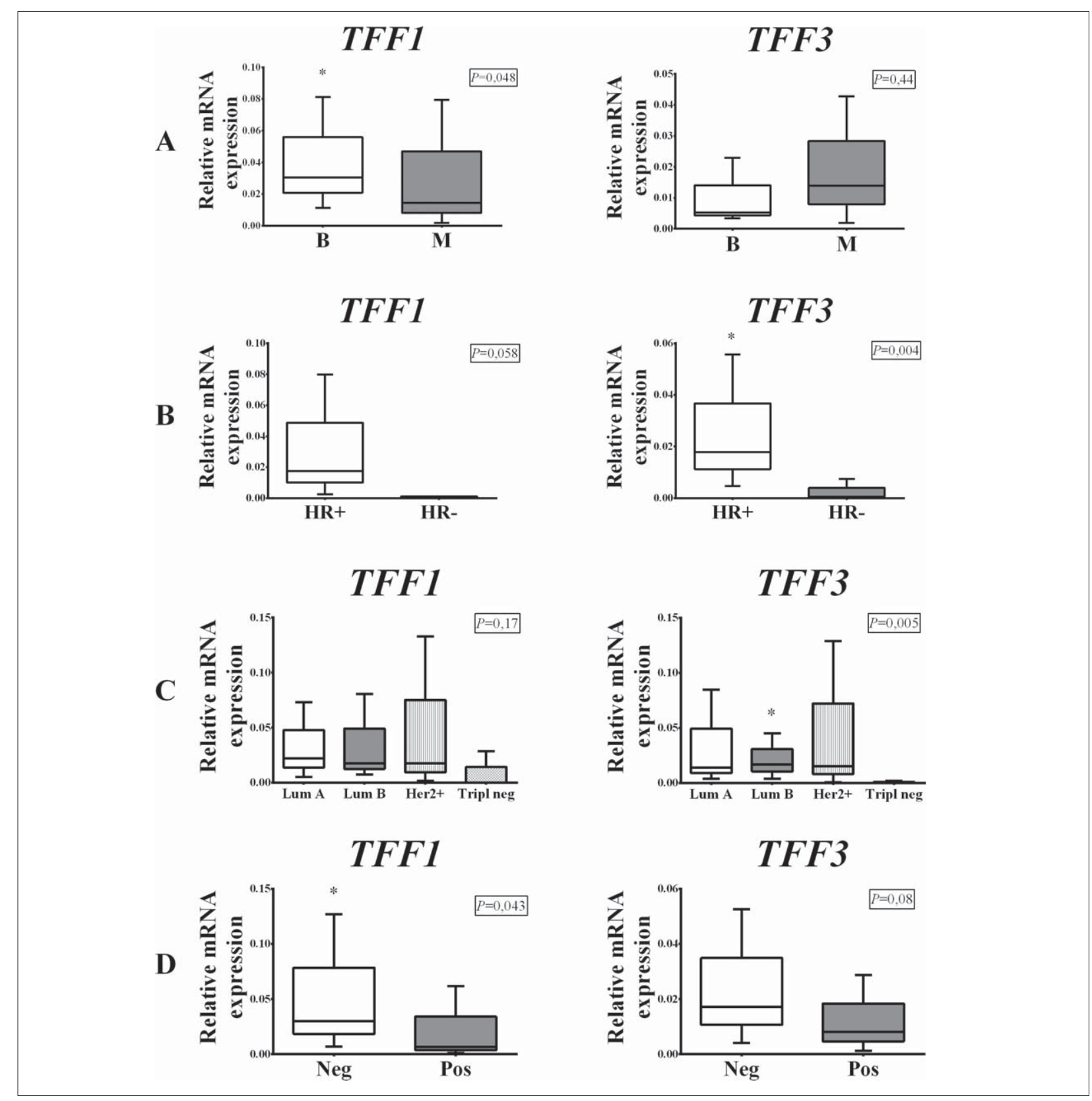

Fig. 1. Distribution of TFF1 and TFF3 $m R N A$ expression in benign (B) and malignant (M) breast tumors (panel $A)$; hormone receptor-positive (HR+) and hormone receptor-negative (HR-) malignant breast tumors (panel B); malignant tumor subgroups according to St. Gallen consensus (panel C); and breast tumors with metastases in lymph nodes (Pos) and without lymph node metastases (Neg) (panel D). The test group comprised of 91 malignant and 31 benign (fibroadenomas) surgically removed human breast tumors. Relative $m R N A$ expression was measured by $q R T$ PCR; all measured genes were normalized to expression of Actin beta (ACTB) gene. Data are presented as median and interquartile range limits, horizontal bars represent the median, boxes indicate the range of the third and second quartiles, and whiskers represent extreme values of all data. Expression of TFF1 was significantly higher in benign tumors (Mann Whitney U test, $p=0.048$ ) and lymph node negative tumors (Mann Whitney U test, $p=0.043$ ), while the levels of TFF3 $m R N A$ were significantly higher in HR+ tumors (Mann Whitney $U$ test, $p=0.004$ ) and Lum $B$ tumors (Kruskal Walis test, $p=0.005$ ); ${ }^{*} p<0.05$ was considered significant. 
strongly expressed in Lum B subgroup ( $\mathrm{p}=0.17$ and $\mathrm{p}=0.005$, respectively) (Fig. 1, panel C). TFF1 and TFF3 expression was higher in subjects with tumors that did not have metastases in lymph nodes (Fig. 1, panel D).

Strong positive correlation between $T F F 1$ and $T F F 3$ was recorded within the malignant tumor group
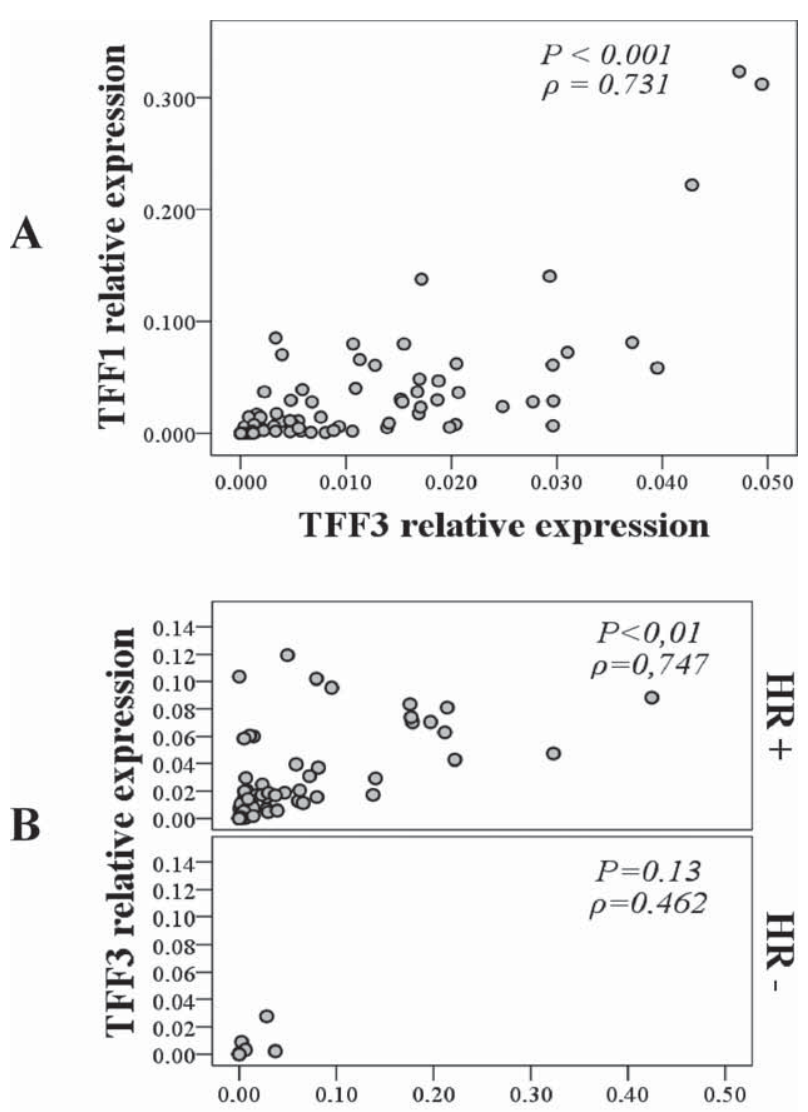

TFF1 relative expression

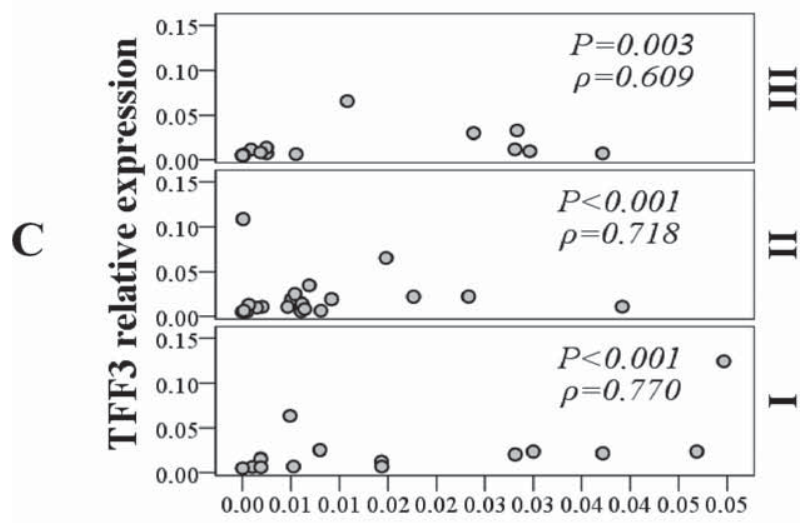

TFF1 relative expression $(\mathrm{p}<0.001 ; \rho=0.731)$ (Fig. 2, panel A) and it was even more prominent in the hormone receptor-positive malignant tumor subgroup $(p<0.001 ; \rho=0.747)$ (Fig. 2, panel B).

Comparing the results between the malignant subgroups defined according to tumor histologic differentiation grade, a significant difference in the expression of TFF1 and TFF3 mRNA was observed. The moderately differentiated tumor subgroup (grade II) had the highest TFF1 and TFF3 expression, while the poorly differentiated tumor group (grade III) had the lowest expression ( $\mathrm{p}=0.008$ and $\mathrm{p}=0.001$, respectively) (Fig. 3, panel A). Strong positive correlation between TFF1 and $T F F 3$ was found in all three subgroups defined by tumor histologic differentiation grade, but was strongest in well-differentiated tumors (grade I) $(\mathrm{p}<0.001$; $\rho=0.770$ ) (Fig. 2, panel C).

When classifying malignant tumors according to the level of Ki67 expression, the highest expression of $T F F 1$ and TFF3 was measured in the group of tumors with moderately high expression of Ki-67 (Fig. 3, panel B). Even though the results did not yield a statistically significant difference in mRNA expression between the subgroups, a mild negative correlation was observed for Ki67 with TFF1 and TFF3 in the malignant group. As Ki67 expression increased, the expression of TFF1 ( $\mathrm{p}=0.028 ; \rho=-0.248)$ (Fig. 4, panel A) and TFF3 ( $\mathrm{p}=0.011 ; \rho=-0.285$ ) (Fig. 4, panel B) decreased significantly. The most prominent correlation was recorded between Ki67 and TFF3 in the hormone receptor-negative tumor subgroup $(\mathrm{p}=0.03 ; \rho=-0.629)$ (Fig. 4, panel C).

↔

Fig. 2. Correlation between TFF1 and TFF3 $m R N A$ expression within the malignant group (panel $A$ ); hormone receptor-positive $(H R+)$ and hormone receptor-negative (HR-) malignant tumor subgroups (panel B); and malignant tumor subgroups defined by bistologic differentiation grade: I (good), II (moderate) and III (poor) (panel C). Strong positive correlation was observed between TFF1 and TFF3 in malignant tumor group (Spearman rank correlation; $p<0.001, \rho=0.731$ ), in HR+ tumor subgroup (Spearman rank correlation; $p<0.001, \rho=0.747$ ) and in tumor subgroups with good bistologic differentiation (Spearman rank correlation; $p<0.001, \rho=770) ;{ }^{*} p<0.05$ was considered significant. 


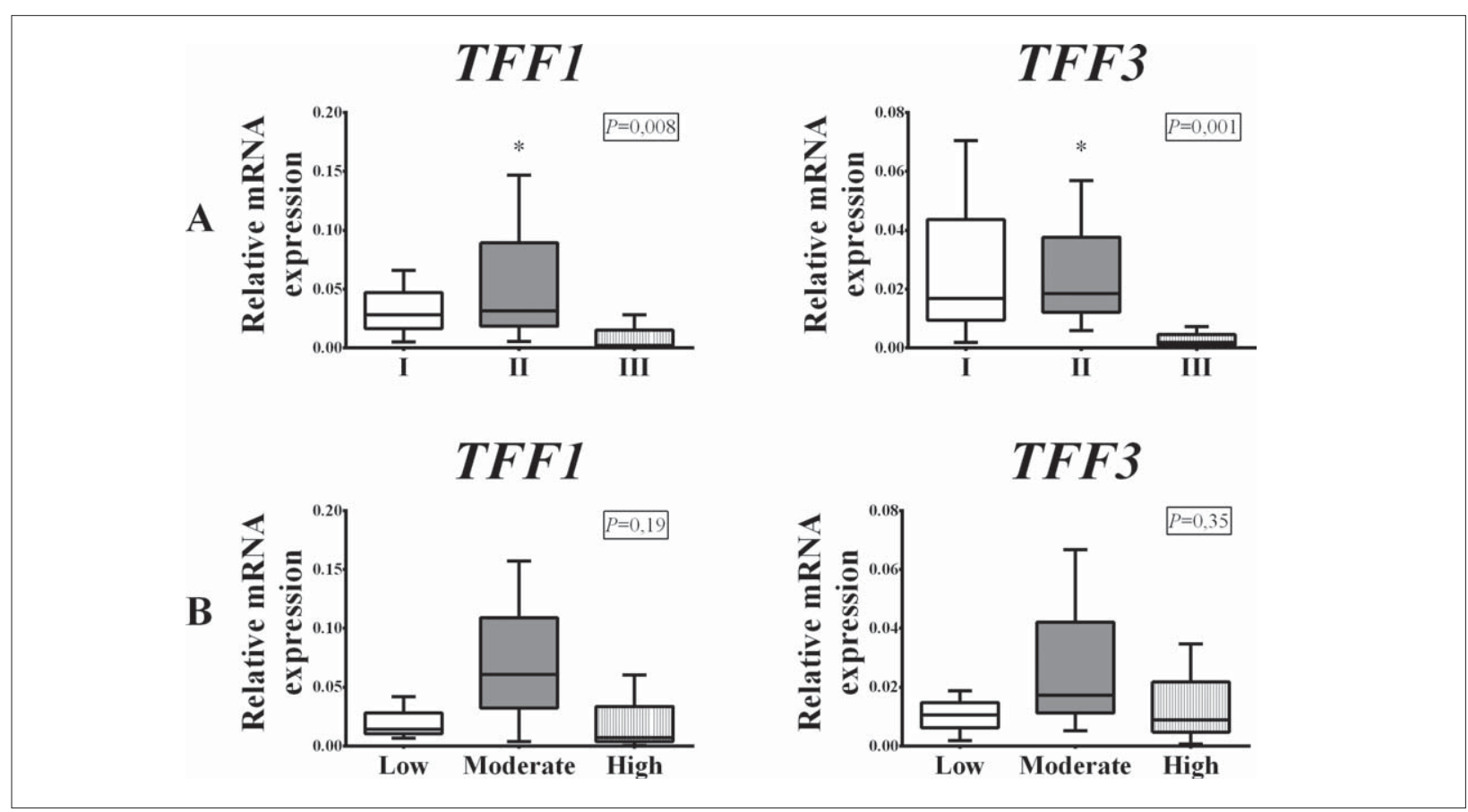

Fig. 3. Distribution of TFF1 and TFF3 $m R N A$ expression depending on histologic tumor grade differentiation: good (I), moderate (II) and poor (III) (panel A) and depending on the expression of proliferation marker Ki67 (\%): low, moderate and high (panel B) within the malignant group of breast tumors. The test group comprised of 91 surgically removed malignant human breast tumors. Relative $m R N A$ expression was measured by $q R T-P C R$; all measured genes were normalized to expression of Actin beta (ACTB) gene. Data are presented as median and interquartile range limits, horizontal bars represent the median, boxes indicate the range of the third and second quartiles, and whiskers represent extreme values of all data. Expression of both TFF1 and TFF3 $m R N A$ was highest in the moderately differentiated (II) tumor subgroup (Kruskal Wallis test, $p=0.008$ and $p=0.001$, respectively) and in tumor subgroup with moderately high expression of Ki-67 (Kruskal Wallis test, $p=0.19$ and $p=0.35$, respectively); ${ }^{*}<0.05$ was considered significant.

\section{TFF protein expression}

The immunohistochemical signal of TFF1 and TFF3 proteins was visible in the cytoplasm of tumor cells and there was no evidence of nuclear immunoreaction (Fig. 5). TFF1 protein expression was higher in the benign tumor group $(\mathrm{p}<0.001)$ (Fig. 6, panel A), whereas TFF3 protein expression was higher in the malignant tumor group $(\mathrm{p}<0.001)$ (Fig. 6, panel A). None of the tumor tissue subgroups, irrespective of malignancy, exhibited TFF2 protein expression (Fig. 7, panel B). Comparing the results between the subgroups defined according to the St. Gallen consensus, Lum A and Lum B tumor subgroups had the highest TFF1 protein expression ( $\mathrm{p}<0.001)$ (Fig. 5, TFF1; Fig. 6 , panel B). TFF3 protein expression was highest in Lum B tumor subgroup ( $\mathrm{p}<0.001)$ (Fig. 5, TFF3; Fig.
6, panel $\mathrm{B})$. The Her2 positive and triple negative tumor subgroups had the lowest expression of both TFF1 and TFF3 proteins.

\section{Discussion}

In the present study, we examined the expression of all three $T F F$ genes and TFF proteins in breast tumor tissue and compared them according to tumor malignancy, differentiation grade, marker of cell proliferation (Ki67), and tendency to produce metastases in axillary lymph nodes. Expression of TFF genes was measured by qRT-PCR from total RNA isolated from tissue samples which had heterogeneous cell population; to make sure that the vast amount of measured mRNA was from tumor tissue, protein products of 
those genes were located by immunohistochemistry. Correlations between $T F F$ within the tumor subgroups, and correlations of $T F F$ with Ki67 and tumor differentiation grade were also examined.

\section{TFF1}

Many in vitro and in vivo studies of TFF1 gene and TFF 1 protein have been performed in the past, however, scientists have not yet agreed about the role
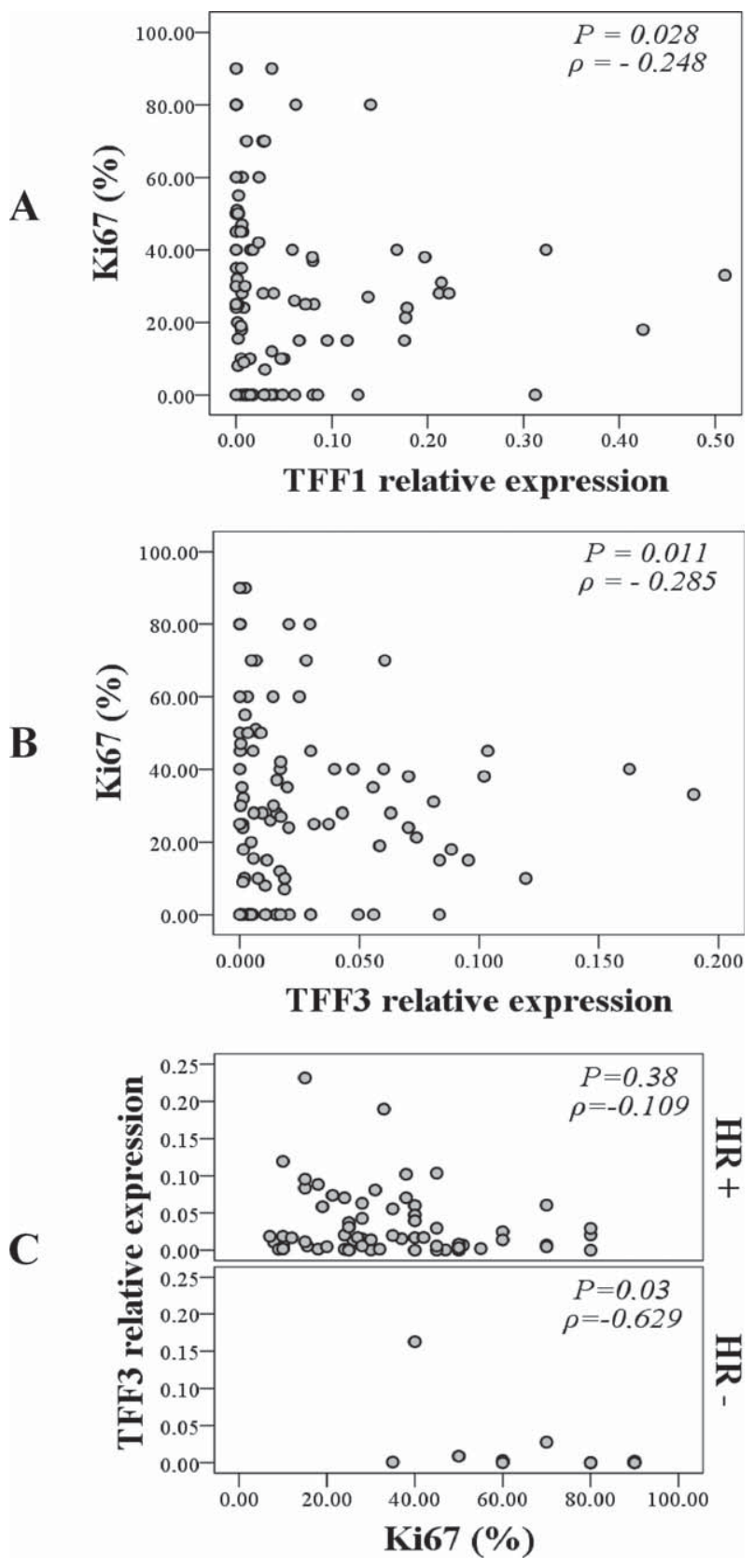

of TFF1 protein in tumor tissue, and whether its action is pro-oncogenic or protective.

This study showed that TFF1 levels were higher in the benign group (fibroadenomas) compared to malignant tumors. When TFF1 levels were compared between malignant tumor subgroups defined by the St. Gallen consensus, we found the highest TFF1 expression in Lum A and Lum B groups, both hormone receptor-positive tumors, which have a higher survival rate than hormone receptor-negative tumors ${ }^{37}$. In the subgroups according to the lymph node status, TFF1 levels were higher in tumors without metastases in lymph nodes, also characterized by higher survival rate $^{38}$. Our findings are in line with the results from several previous studies indicating a high level of TFF1 gene expression in breast tumors as a biomarker of good prognosis, in spite of the fact that different molecular methods and different tumor classifications and models were used ${ }^{18,19}$. The study by Buache et al. demonstrated that TFF1 knock-out mice had a higher incidence and larger mammary cancers than wild-type mice, and in vitro experiment, performed in the same study, on estrogen receptor-positive and estrogen receptor-negative cell lines showed that TFF1 protein did not have oncogenic qualities ${ }^{18}$. Similarly, the study by Corte et al. showed that high cytosolic levels of TFF1 were associated with better clinical outcome and prolonged overall survival ${ }^{19}$. Even though the expression of TFF1 mRNA in our study was highest in

↔

Fig. 4. Correlation between TFF1 mRNA expression and expression of proliferation marker Ki67 (\%) within the malignant tumor group (panel A), TFF3 mRNA expression and expression of Ki67 (\%) within the malignant tumor group (panel B) and correlation between TFF3 mRNA expression and expression of Ki67 (\%) in the hormone receptor-positive (HR+) and in the hormone receptor-negative (HR-) malignant tumor subgroup (panel C). Mild negative correlation was observed between TFF1 and Ki67 and between TFF3 and Ki67 within the malignant tumor group (Spearman rank correlation; $p=0.028 ; \rho=-0.248$ and $p=0.011 ; \rho=-$ 0.285 , respectively) and strong negative correlation between TFF3 and Ki67 within HR-tumor subgroup (Spearman rank correlation; $p=0.03 ; \rho=-0.629$ ); ${ }^{*} p<0.05$ was considered significant. 
tumors with moderately high Ki67 expression, the lowest values were measured in the tumor subgroup with high expression of Ki67. Results of TFF1 protein expression reflected our findings on the TFF1 gene expression analysis. Additionally, analysis of the correlation between TFF1 gene and Ki67 showed that the expression of TFF1 decreased as Ki67 increased. Such findings support the thesis that the higher expression of TFF1 means better prognosis for breast tumor patients, as it is known that the malignancy of a tumor increases as Ki67 increases ${ }^{39}$.

\section{TFF2}

Our results showed a very low level of TFF2 mRNA expression in benign breast tumor samples and almost no expression in malignant breast tumors. Consistently, immunohistochemical analysis did not reveal TFF2 protein expression in a single sample. Our results are in accordance with the results of several previous studies that detected $T F F 2$ gene expression in breast tumor cell lines, but not in human tissue $22,23,40$. The observed difference between in vivo and in vitro experiments could be due to the greater number of parameters influencing regulation, expression and role of TFF2 gene and protein in in vivo conditions. Based on our findings, TFF2 gene and TFF2 protein have very poor potential as biomarkers for breast tumor assessment.

\section{TFF3}

In this study, TFF3 was expressed in all tumor samples, but the highest expression was found in malignant tumors, unlike TFF1, which was highly expressed in benign tumors (fibroadenomas). The highest level of TFF3 expression among the malignant tumor subgroups (defined according to St. Gallen consensus) was in Lum B group, which is a hormone receptor-positive tumor subgroup. Additionally, the highest level of TFF3 expression was detected in grade I and grade II tumors, which conforms to the studies by Ahmed et al. and May and Westley, who found that TFF3 expression was higher in grade I tumors and in tumors with estrogen and progesterone receptor expression $^{26,43}$. When the expression was compared among the subgroups with different levels of Ki67 expression, the highest TFF3 expression was observed in the tumor subgroup with moderately high Ki67 expression. The TFF3 mRNA levels were higher in tu-

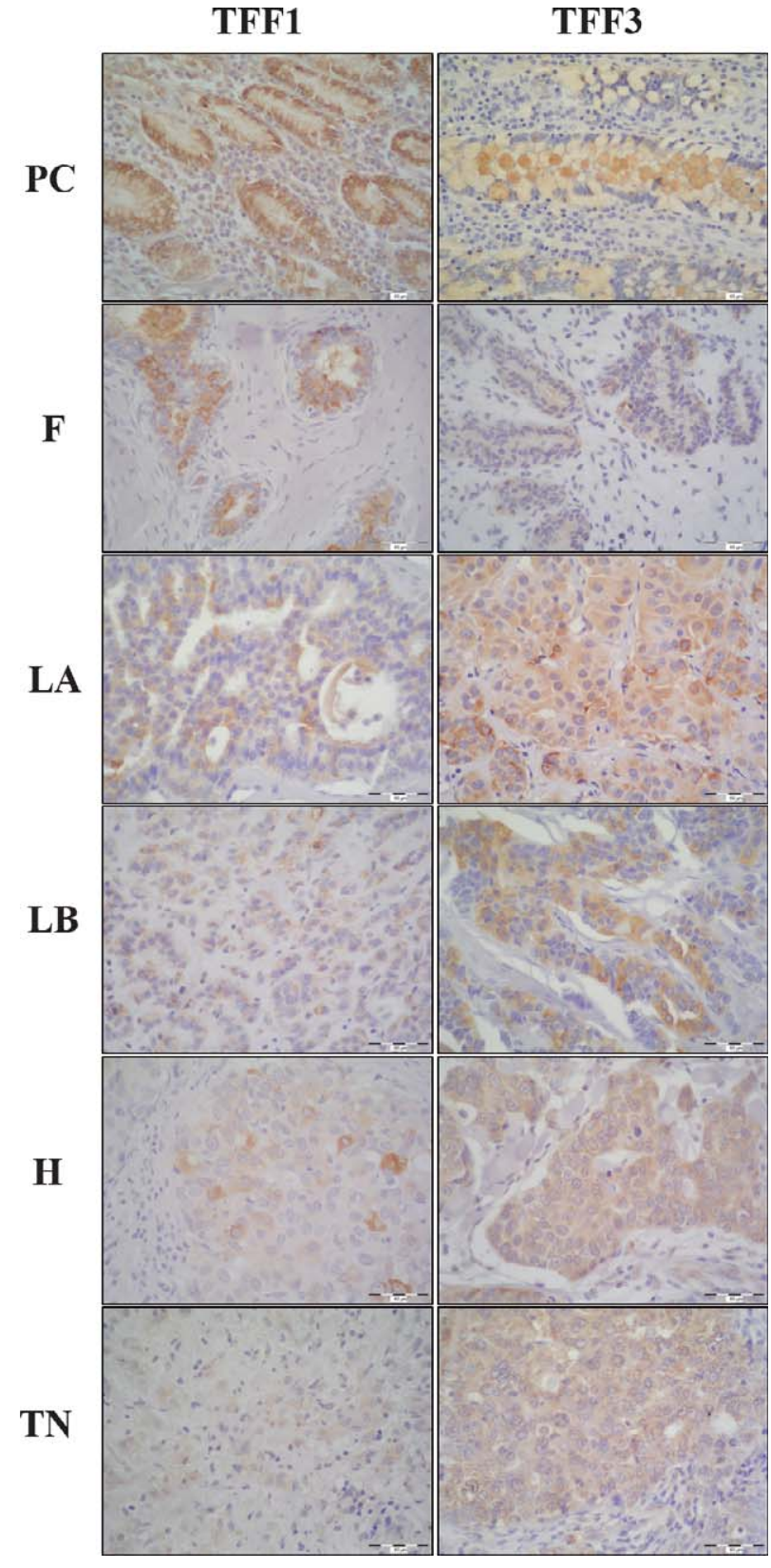

Fig. 5. Expression of TFF1 and TFF3 proteins in breast tumors. The test group comprised of 60 malignant human breast tumors and 15 benign (fibroadenomas) human breast tumors, surgically removed. Tumor tissues were collected intraoperatively, formalin-fixed, paraffinembedded, and analyzed by immunohistochemistry. The immunohistochemical signal is visible in the cytoplasm of tumor cells. Representative examples of immunoreaction with gastric mucosa as positive control for TFF1 and colon mucosa for TFF3 (PC), fibroadenoma $(F)$, Luminal $A$ $(L A)$, Luminal B (LB), Her2 positive $(H)$ and triple negative tumors (TN) are shown. Scale bar, $60 \mu \mathrm{m}$. 


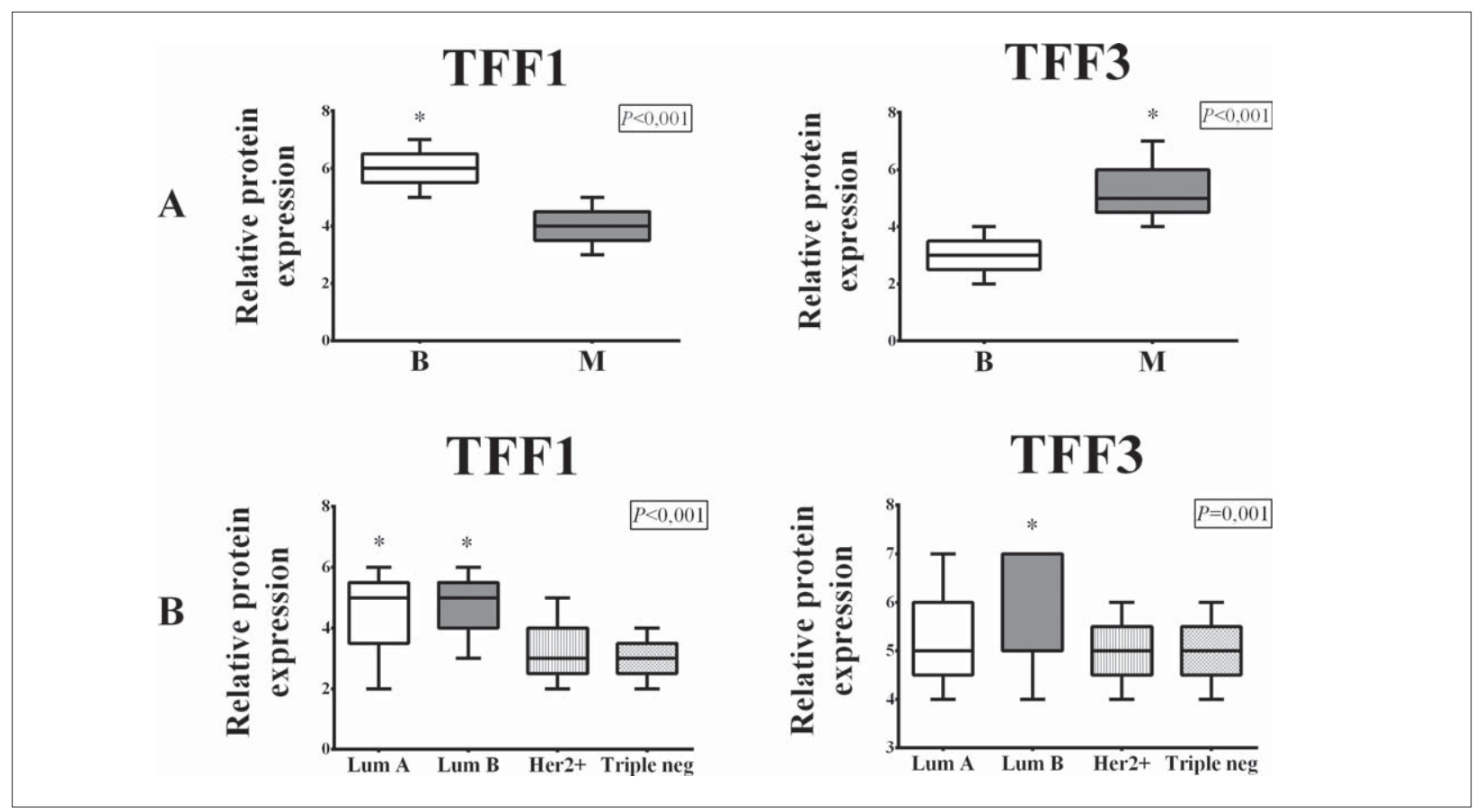

Fig. 6. Distribution of TFF1 and TFF3 protein expression in benign (B) and malignant (M) breast tumors (panel A) and malignant tumor subgroups according to St. Gallen consensus (panel B). The test group comprised of 60 malignant human breast tumors and 15 benign (fibroadenomas) human breast tumors, surgically removed. Protein expression was assessed by immunohistochemistry and histomorphological analysis was performed using the modified Quick Score method. Data are presented as median and interquartile range limits, horizontal bars represent the median, boxes indicate the range of the third and second quartiles, and whiskers represent extreme values of all data. Expression of TFF1 was significantly higher in benign tumors (Mann Whitney U test, $p<0.001$ ), while the expression of TFF3 was significantly higher in malignant tumors (Mann Whitney U test, $p=0.001$ ). According to the St. Gallen consensus subgroups, significantly highest TFF1 expression was in Luminal A and Luminal B tumor subgroups (Kruskal Wallis test, $p<0.001$ ) and significantly highest TFF3 expression was in Luminal B tumor subgroup (Kruskal Wallis test, $p=0.001) ;{ }^{*} p<0.05$ was considered significant.

mors without metastases in lymph nodes than in tumors that had spread into local or distant lymph nodes. These results are in contrast to the findings of the studies by Ahmed et al. and Pandey et al..$^{26,29}$. The study by Ahmed et al., based on multivariate binary logistic regression analysis of several clinicopathologic features and molecular biomarkers, concluded that the higher expression of TFF3 protein could be a metastatic tumor dissemination predictor ${ }^{26}$. Similarly, Pandey et al. conclude, based on TFF protein analysis in breast tumors, that the TFF3 protein expression is significantly associated with lymph node metastasis and stimulates cellular invasion, and is therefore a metastatic tumor dissemination predictor ${ }^{29}$. Strong positive correlation between $T F F 1$ and $T F F 3$, especially in tumors with a lower degree of malignancy, are consistent with the findings that TFF1 and TFF3 have the same controlling mechanisms, such as estrogen responsiveness ${ }^{41,42}$. Our findings of negative correlation between TFF3 and Ki67 and positive correlation between TFF3 and $T F F 1$ in hormone receptor-negative tumors suggested that the patients diagnosed with hormone receptornegative tumors with high levels of TFF3 expression could also benefit from endocrine therapy because it is known that both TFF1 and TFF3 genes are regulated by estrogen ${ }^{41,42}$. This is further supported in the study by May and Westley, showing that TFF3 expression is an independent predictive biomarker of both estrogen response and degree of response ${ }^{43}$. Consistently to previous findings, we demonstrated that the expression of TFF3 protein corresponded to the TFF3 mRNA expression. 

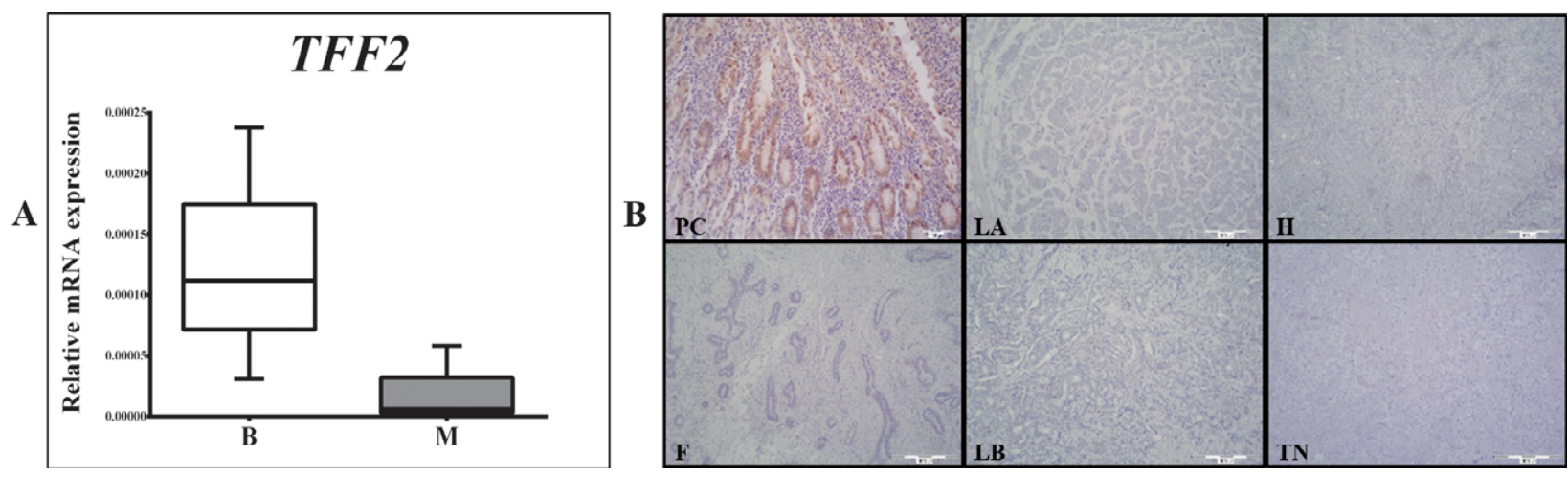

Fig. 7. Distribution of TFF2 $m R N A$ expression in benign (B) (fibroadenomas) and malignant (M) breast tumors. The test group comprised of 91 malignant and 31 benign (fibroadenomas) surgically removed human breast tumors. Relative $m R N A$ expression was measured by $q R T$ - PCR; all measured genes were normalized to expression of Actin beta (ACTB) gene. Data are presented as median and interquartile range limits, horizontal bars represent the median, boxes indicate the range of the third and second quartiles, and whiskers represent extreme values of all data. The level of TFF2 $m R N A$ expression in benign breast tumors (B) was very low while in malignant tumors (M) TFF2 $m R N A$ was not expressed (panel $A$ ). Expression of TFF2 protein in breast tumors: the test group comprised of 60 malignant buman breast tumors and 15 benign (fibroadenomas) human breast tumors, surgically removed. Tumor tissues were collected intraoperatively, formalin-fixed, paraffin-embedded, and analyzed by immunohistochemistry. Representative examples of immunoreaction with gastric mucosa as positive control for TFF2 (PC), fibroadenoma $(F)$, Luminal $A$ (LA), Luminal B (LB), Her2 positive (H) and triple negative (TN) malignant subgroups are shown. None of the tumor tissue subgroups, irrespective of malignancy, exhibited TFF2 protein expression. Scale bar, $300 \mu m$ (panel B).

In this study, we demonstrated the presence of TFF1 and TFF3 mRNA and their corresponding protein products in the investigated breast tumors with variable expression levels among different tumor subgroups, while the TFF2 mRNA and TFF2 protein levels were low or undetectable. Our results suggest that TFF1 and TFF3, unlike TFF2, may have a role in breast tumor pathogenesis and could be used in the assessment of tumor malignancy only in particular breast tumor subgroups. Increased expression of TFF1 could be used as a potential biomarker indicating a good prognosis, while TFF3 could be helpful in tumor status assessment; however, additional in vivo studies are needed to reach an agreement on the exact clinical impact of TFF molecules and their activity in breast tumor tissues.

\section{References}

1. Ferlay J, Soerjomataram I, Dikshit R, Eser S, Mathers C, Rebelo $\mathrm{M}$, et al. Cancer incidence and mortality worldwide: sources, methods and major patterns in GLOBOCAN 2012. Int J Cancer. 2015;1;136(5):E359-386.

DOI: $10.1002 / \mathrm{ijc} .29210$
2. Rosen PP, Hoda SA, Brogi E, Koerner FC; Rosen's Breast Pathology, $4^{\text {th }}$ edn. Lippincott Williams \&Wilkins, Philadelphia; 2014.

3. Gnant M, Harbeck N, Thomssen C. St. Gallen 2011: Summary of the Consensus Discussion. Breast Care. 2011;6(2):136-41. DOI: $10.1159 / 000328054$

4. Falck AK, Fernö M, Bendahl PO, Rydén L. St Gallen molecular subtypes in primary breast cancer and matched lymph node metastases - aspects on distribution and prognosis for patients with luminal A tumours: results from a prospective randomised trial. BMC Cancer. 2013;25;13:558. DOI: 10.1186/14712407-13-558.

5. Stopeck AT, Brown-Glaberman U, Wong HY, Park BH, Barnato SE, Gradishar WJ, et al. The role of targeted therapy and biomarkers in breast cancer treatment. Clin Exp Metastasis. 2012;1;29(7):807-19. DOI: 10.1007/s10585-012-9496-y

6. Hoffmann W, Jagla W, Wiede A. Molecular medicine of TFFpeptides: from gut to brain. Histol Histopathol. 2001;16(1): 319-34. DOI: 10.14670/HH-16.319

7. Madsen J, Nielsen O, Tornøe I, Thim L, Holmskov U. Tissue localization of human trefoil factors 1, 2, and 3. J Histochem Cytochem. 2007;55(5):505-13.

8. Williams GR, Wright NA. Trefoil factor family domain peptides. Virchows Arch Int J Pathol. 1997;431(5):299-304.

9. Regalo G, Wright NA, Machado JC. Trefoil factors: from ulceration to neoplasia. Cell Mol Life Sci CMLS. 2005;62 (24):2910-5. DOI: 10.1007/s00018-005-5478-4 
10. Perry JK, Kannan N, Grandison PM, Mitchell MD, Lobie PE. Are trefoil factors oncogenic? Trends Endocrinol Metab TEM. 2008;19(2):74-81.10.1016/j.tem.2007.10.003

11. Belovari T, Bijelić N, Levak MT, Lončar MB. Trefoil factor family peptides TFF1 and TFF3 in the nervous tissues of developing mouse embryo. Bosn J Basic Med Sci. 2015;15(1): 33-7.

12. Busch M, Dünker N. Trefoil factor family peptides - friends or foes? Biomol Concepts. 2015;6(5-6):343-59. DOI 10.1515/ bmc-2015-0020

13. Prest SJ, May FEB, Westley BR. The estrogen-regulated protein, TFF1, stimulates migration of human breast cancer cells. FASEB J. 2002;16(6):592-4.

14. Amiry N, Kong X, Muniraj N, Kannan N, Grandison PM, Lin $\mathrm{J}$, et al. Trefoil factor-1 (TFF1) enhances oncogenicity of mammary carcinoma cells. Endocrinology. 2009;150(10):4473-83. DOI: 10.1210/en.2009-0066

15. Smid M, Wang Y, Klijn JGM, Sieuwerts AM, Zhang Y, Atkins $\mathrm{D}$, et al. Genes associated with breast cancer metastatic to bone. J Clin Oncol. 2006;20;24(15):2261-7.

DOI: $10.1200 / \mathrm{JCO} .2005 .03 .8802$

16. Crosier M, Scott D, Wilson RG, Griffiths CD, May FE, Westley BR. High expression of the trefoil protein TFF1 in interval breast cancers. Am J Pathol. 2001;159(1):215-21. DOI: 10.1016/S0002-9440(10)61687-2

17. Foekens JA, van Putten WL, Portengen H, de Koning HY, Thirion B, Alexieva-Figusch J, et al. Prognostic value of PS2 and cathepsin $\mathrm{D}$ in 710 human primary breast tumours: multivariate analysis. J Clin Oncol. 1993;11(5):899-908.

18. Buache E, Etique N, Alpy F, Stoll I, Muckensturm M, ReinaSan-Martin B, et al. Deficiency in trefoil factor 1 (TFF1) increases tumorigenicity of human breast cancer cells and mammary tumour development in TFF1-knockout mice. Oncogene. 2011;21;30(29):3261-73. DOI: 10.1038/onc.2011.41

19. Corte MD, Tamargo F, Alvarez A, Rodríguez JC, Vázquez J, Sánchez R, et al. Cytosolic levels of TFF1/pS2 in breast cancer: their relationship with clinical-pathological parameters and their prognostic significance. Breast Cancer Res Treat. 2006; 96(1):63-72. DOI: 10.1007/s10549-005-9041-7

20. Surowiak P, Materna V, Györffy B, Matkowski R, Wojnar A, Maciejczyk A, et al. Multivariate analysis of oestrogen receptor alpha, pS2, metallothionein and CD24 expression in invasive breast cancers. Br J Cancer. 2006;7;95(3):339-46. DOI: 10.1038/sj.bjc.6603254

21. Poulsom R, Hanby AM, Lalani EN, Hauser F, Hoffmann W, Stamp GW. Intestinal trefoil factor (TFF 3) and pS2 (TFF 1), but not spasmolytic polypeptide (TFF 2) mRNAs are co-expressed in normal, hyperplastic, and neoplastic human breast epithelium.J Pathol. 1997;183(1):30-8.

22. May FEB, Semple JI, Prest SJ, Westley BR. Expression and motogenic activity of TFF2 in human breast cancer cells. Peptides. 2004;25(5):865-72.

DOI: $10.1016 /$ j.peptides.2003.12.024
23. Lalani EN, Williams R, Jayaram Y, Gilbert C, Chaudhary KS, Siu LS, et al. Trefoil factor-2, human spasmolytic polypeptide, promotes branching morphogenesis in MCF-7 cells. Lab Investig J Tech Methods Pathol. 1999;79(5):537-46.

24. Siu LS, Romanska H, Abel PD, Baus-Loncar M, Kayademir T, Stamp GWH, et al. TFF2 (trefoil family factor 2) inhibits apoptosis in breast and colorectal cancer cell lines. Peptides. 2004;25(5):855-63. DOI: 10.1016/j.peptides.2003.11.023

25. Chi AL, Lim S, Wang TC. Characterization of a CCAATenhancer element of trefoil factor family 2 (TFF2) promoter in MCF-7 cells. Peptides. 2004;25(5):839-47. DOI: 10.1016/j. peptides.2003.11.022

26. Ahmed ARH, Griffiths AB, Tilby MT, Westley BR, May FEB. TFF3 is a normal breast epithelial protein and is associated with differentiated phenotype in early breast cancer but predisposes to invasion and metastasis in advanced disease. Am J Pathol. 2012;180(3):904-16.

DOI: 10.1016/j.ajpath.2011.11.022

27. Emami S, Rodrigues S, Rodrigues CM, Le Floch N, Rivat C, Attoub S, et al. Trefoil factor family (TFF) peptides and cancer progression. Peptides. 2004;25(5):885-98. DOI: 10.1016/j. peptides.2003.10.019

28. Lau WH, Pandey V, Kong X, Wang XN, Wu Z, Zhu T, et al. Trefoil factor-3 (TFF3) stimulates de novo angiogenesis in mammary carcinoma both directly and indirectly via IL-8/ CXCR2. PloS One. 2015;10(11):e0141947. DOI: 10.1371/ journal.pone.0141947

29. Pandey V,Wu ZS, Zhang M, Li R, Zhang J, Zhu T, et al. Trefoil factor 3 promotes metastatic seeding and predicts poor survival outcome of patients with mammary carcinoma. Breast Cancer Res. 2014;30;16(5):429. DOI: 10.1186/s13058-014-0429-3

30. Utrera-Barillas D, Valdez-Salazar HA, Gómez-Rangel D, Alvarado-Cabrero I, Aguilera P, Gómez-Delgado A, RuizTachiquin ME. Is human cytomegalovirus associated with breast cancer progression? Infect Agent Cancer. 2013;8(1):12. DOI: 10.1186/1750-9378-8-12.

31. Rakha EA, Reis-Filho JS, Baehner F, Dabbs DJ, Decker T, Eusebi $\mathrm{V}$, et al. Breast cancer prognostic classification in the molecular era: the role of histological grade. Breast Cancer Res. 2010;12(4):207. DOI: 10.1186/bcr2607

32. Loncar MB, Al-azzeh E, Sommer PSM, Marinovic M, Schmehl $\mathrm{K}$, Kruschewski M, et al. Tumour necrosis factor alpha and nuclear factor kappa B inhibit transcription of human TFF3 encoding a gastrointestinal healing peptide. Gut. 2003;52 (9):1297-303.

33. Wang H, Yanga B, Gengb T, Li B, Dai P, Chen C. Tissue-specific selection of optimal reference genes for expression analysis of anti-cancer drug-related genes in tumor samples using quantitative real-time RT-PCR. Exp Mol Pathol. 2015;98 (3):375-81. DOI: 10.1016/j.yexmp.2014.10.014

34. Bijelić N, Belovari T, Tolušić Levak M, Lončar MB. Localization of trefoil factor family peptide 3 (TFF3) in epithelial tissues originating from the three germ layers of developing 
mouse embryo. Bosn J Basic Med Sci. 2017;17(3):241-7. DOI: 10.17305/bjbms.2017.1838

35. Mudduwa L, Liyanage T. Immunohistochemical assessment of hormone receptor status of breast carcinoma: interobserver variation of the quick score. Indian J Med Sci. 2009;63(1):21-7.

36. Detre S, Saclani Jotti G, Dowsett M. A “quickscore" method for immunohistochemical semiquantitation: validation for oestrogen receptor in breast carcinomas. J Clin Pathol. 1995;48(9): 876-8.

37. Goldhirsch A, Winer EP, Coates AS, Gelber RD, Piccart-Gebhart M, Thürlimann $\mathrm{B}$, et al. Personalizing the treatment of women with early breast cancer: highlights of the St Gallen International Expert Consensus on the Primary Therapy of Early Breast Cancer 2013. Ann Oncol. 2013;24(9):2206-23. DOI. 10.1093/annonc/mdt303

38. Chagpar A, Middleton LP, Sahin AA, Meric-Bernstam F, Kuerer HM, Feig BW, et al. Clinical outcome of patients with lymph node-negative breast carcinoma who have sentinel lymph node micrometastases detected by immunohistochemistry. Cancer. 2005;15;103(8):1581-6: DOI: 10.1002/cncr.20934
39. Abubakar M, Orr N, Daley F, Coulson P, Ali HR, Blows F, et al. Prognostic value of automated KI67 scoring in breast cancer: a centralised evaluation of 8088 patients from 10 study groups. Breast Cancer Res. 2016;Oct 18;18(1):104. DOI: 10.1186/s13058-016-0765-6

40. Ishibashi Y, Hiroshi O, Ikemura M, Kikuchi Y, Niwa T, Nishioka K, Uchida Y, Miura H, et al. Serum TFF1 and TFF3 but not TFF2 are higher in women with breast cancer than in women without breast cancer. Sci Rep. 2017;7(1):4846. doi: 10.1038/s41598-017-05129-y.

41. Berry M, Nunez AM, Chambon P. Estrogen-responsive element of the human $\mathrm{pS} 2$ gene is an imperfectly palindromic sequence. Proc Natl Acad Sci U S A. 1989;86(4):1218-22.

42. May FE, Westley BR. Expression of human intestinal trefoil factor in malignant cells and its regulation by oestrogen in breast cancer cells. J Pathol. 1997;182(4):404-13.

43. May FEB, Westley BR. TFF3 is a valuable predictive biomarker of endocrine response in metastatic breast cancer. Endocr Relat Cancer. 2015;22(3):465-79.

DOI: $10.1530 /$ ERC-15-0129

Sažetak

\title{
IZRAŽAJ TFF GENA I PROTEINA U TUMORIMA DOJKE
}

\author{
M. Tolusicí Levak, M. Mibalj, I. Koprivčić, I. Lovrić, S. Novak, N. Bijelic, \\ M. Baus-Lončar, T. Belovari, K. Kralik i B. Pauzar
}

Cilj ovoga istraživanja bio je utvrditi razlike u izražaju gena i proteina TFF1, TFF2 i TFF3 u različitim vrstama tumora dojke te ispitati korelacije između gena $T F F$ i vrsta tumora te gena $T F F$ i kliničko-patoloških karakteristika tumora. U studiju su bile uključene 122 ispitanice kojima je kirurški odstranjen tumor dojke. Uzorci su obrađeni metodom qRT-PCR i metodom imunohistokemije. Geni i proteini TFF1 i TFF3 bili su izraženi u tumorima dojke, dok izražaj gena i proteina TFF2 nije otkriven u tumorskom tkivu. TFF1 je bio izraženiji kod dobroćudnih tumora, dok je TFF3 bio izraženiji kod zloćudnih tumora. TFF1 i TFF3 su bili izraženiji u hormonski ovisnim tumorima, tumorima bez metastaza u limfnim čvorovima, tumorima s umjereno visokim izražajem Ki67 i umjereno diferenciranim tumorima. Jaka pozitivna korelacija uočena je između gena TFF1 i TFF3, a oba su negativno korelirala s faktorom Ki67 i stupnjem diferenciranosti tumora. Dobiveni rezultati pokazuju kako bi TFF1 i TFF3 mogli imati ulogu u patogenezi tumora dojke te bi se potencijalno mogli rabiti za određivanje tumorskog statusa i procjenu malignosti tumora.

Ključne riječi: tumorski proteini; dojka, tumori; imunohistokemija; lančana reakcija polimerazom; limfni čvorovi; Ki-67 antigen; biomarkeri 